\title{
Penyuluhan Pembuatan dan Penyemprotan Desinfektan pada Warga Desa Panca Jaya Kecamatan Muara Kaman
}

\author{
Siska Oktaviani ${ }^{1 *}$, Destianti Catur Lia ${ }^{2}$ \\ 1,2Universitas Widya Gama Mahakam, Samarinda, Indonesia \\ *Corresponding Author: siska@uwgm.ac.id
}

Info Artikel

Diterima : $16 / 01 / 2022$

Direvisi: $18 / 01 / 2022$

Disetujui: $19 / 01 / 2022$

\begin{abstract}
There are several ways that can be done to prevent the transmission of Covid-19, one of which is by spraying disinfectant in the surrounding environment and objects that are at risk of transmitting the virus. Making your own disinfectant at home can actually be done using ingredients that are household cleaning products. However, many people from Panca Jaya village, Muara Kaman sub-district, Kutai Kartanegara district, still don't know how to make a disinfectant, even if they know they generally just mix chemicals with water without knowing the content, properties and dosages that will be used to make the disinfectant. Seeing this in the field, it is necessary to have educational activities for the community regarding the manufacture of disinfectants. The purpose of this community service is to provide knowledge and understanding to the residents of Panca Jaya village about how to make disinfectants with home cleaning products in their respective homes. The method used in this counseling was to provide information via LCD and give out pamphlets to participants, demonstrate to make disinfectant, then continue spraying disinfectant in the surrounding environment. It is hoped that this activity can be applied in their daily life as a form of prevention and transmission of Covid-19.
\end{abstract}

Keywords: Disinfectant, Covid-19, Panca Jaya village

\begin{abstract}
Abstrak. Ada beberapa cara yang dapat dilakukan untuk mencegah penularan Covid-19, salah satunya dengan menyemprotkan desinfektan di lingkungan sekitar serta benda-benda yang beresiko menularakan virus. Membuat desinfektan sendiri di rumah sebenarnya bisa dilakukan dengan menggunakan bahan yang merupakan produk pembersih rumah tangga. Namun, masyarakat desa Panca Jaya, kecamatan Muara Kaman, kabupaten Kutai Kartanegara, masih banyak yang belum mengetahui cara membuat desinfektan, jikapun tahu pada umumnya mereka hanya sekedar mencampurkan bahan kimia dengan air tanpa mengetahui kandungan, sifat serta takaran yang akan digunakan untuk membuat desinfektan. Melihat hal tersebut di lapangan, maka perlu adanya kegiatan edukasi bagi masyarakat mengenai pembuatan desinfektan. Tujuan pengabdian masyarakat ini untuk memberikan pengetahuan serta pemahaman kepada warga desa Panca Jaya mengenai cara pembuatan desinfektan dengan produk pembersih rumah yang ada di rumah mereka masing-masing. Metode yang dilakukan pada penyuluhan ini memberi informasi melalui LCD dan pemberian pamflet kepada peserta, demonstrasi membuat desinfektan, kemudian dilanjut penyemprotan desinfektan di lingkungan sekitar. Diharapkan kegiatan ini dapat mereka terapkan dalam kehidupan sehari-hari sebagai bentuk pencegahan dan penularan Covid-19.
\end{abstract}

Kata Kunci: Desinfektan, Covid-19, Desa Panca Jaya

How to Cite: Oktaviani, S., \& Lia, D. C. (2022). Penyuluhan Pembuatan dan Penyemprotan Desinfektan pada Warga Desa Panca Jaya Kecamatan Muara Kaman. Prima Abdika: Jurnal Pengabdian Masyarakat, 2(1), 1-5. https://doi.org/10.37478/abdika.v2i1.1579

(7) (2) Copyright (c) 2022 Siska Oktaviani, Destianti Catur Lia. This work is licensed under a Creative Commons Attribution-ShareAlike 4.0 International License.

\section{Pendahuluan}

Virus corona hampir 2 tahun merebak di Indonesia. Kondisi penderita Covid-19 pun mengalami fluktuasi. Menurut (World Health Organization, 2020) penderita Covid-19 di Indonesia mengalami kenaikan di bulan Juli 2021, pasalnya di 15 Juli 2021 kasus baru penderita Covid-19 mencapai 56.757 kasus. Walaupun pada bulan Oktober 2021 kasus baru penderita Covid-19 mengalami penurunan karena per tanggal 7 Oktober 2021 kasus baru terdapat 1.393 kasus, namun kita tetap tidak boleh lengah.

Virus Covid 19 sangat mudah menular. Virus dapat berpindah ke tubuh kita, bila tanpa sengaja kita menyentuh benda-benda tersebut lalu menyentuh wajah seperti mata, mulut, dan hidung dengan 
tangan yang telah terkontaminasi (Sijabat \& Sijabat, 2021; Fredy et al., 2021). Oleh karena itu, upaya-upaya pencegahan Covid-19 tetap wajib dilakukan, seperti menggunakan masker, jaga jarak, menjauhi kerumunan, mencuci tangan, menggunakan hand sanitizer dan membersihkan bendabenda dengan cairan desinfektan (Tribun Jatim, 2020).

Bentuk pencegahan lain dari penyebaran dan penularan virus Covid-19 dengan selalu menjaga kebersihan lingkungan dan diri sendiri. Selain itu, kita perlu menjaga perilaku hidup bersih dan sehat (Asharo et al., 2021). Ada beberapa cara yang dapat dilakukan untuk mencegah penularan Covid-19, salah satunya menurut (Marzuarman, Hadi, \& Lianda, 2020) dengan menyemprotkan desinfektan di lingkungan sekitar serta benda-benda yang beresiko menularakan virus.

Menurut Budiawan (2012) desinfektan merupakan bahan kimia yang dapat digunakan untuk membunuh mikroorganisme pada benda-benda yang ada di lingkungan yang sering kita sentuh, seperti gagang pintu, railing tangga, kran westafel, kursi, meja dan lain-lain. Sebelumnya dalam penggunaan bahan-bahan kimia seperti desinfektan dan antiseptik, tenaga medis di rumah sakit merupakan pihak yang bertanggung jawab dalam penggunaannya. Namun, mengingat pencegahan dan penularan Covid-19 ini perlu dilakukan bersama, maka di rumah pun perlu menyediakan dan melakukan pembersihan dengan cairan desinfektan (Larasati \& Haribowo, 2020).

Membuat desinfektan sendiri di rumah sebenarnya bisa kita lakukan dengan menggunakan bahan yang merupakan produk pembersih rumah tangga. Menurut (Tribun Jatim, 2020) desinfektan yang direkomendasikan untuk digunakan adalah cairan pembersih karbol yang mengandung benzalkonium klorida atau cairan pemutih pakaian yang mengandung natrium hipoklorit. Upaya menjaga kebersihan lingkungan rumah dan sekitar bukan hanya menjadi tanggung jawab pemerintah saja, melainkan juga menjadi tanggung jawab masyarakat, termasuk masyarakat desa Panca Jaya, kecamatan Muara Kaman, kabupaten Kutai Kartanegara.

Oleh karena itu, pemerintah menghimbau agar masyarakat dapat membuat desinfektan sendiri dan melakukan penyemprotan di lingkungan rumah masing-masing. Namun, masyarakat desa Panca Jaya masih banyak yang belum mengetahui cara membuat desinfektan, jikapun tahu pada umumnya mereka hanya sekedar mencampurkan bahan kimia dengan air tanpa mengetahui kandungan, sifat serta takaran yang akan digunakan untuk membuat desinfektan. Melihat hal tersebut di lapangan, maka perlu adanya kegiatan edukasi bagi masyarakat mengenai pembuatan desinfektan sekaligus melakukan penyemprotan lingkungan desa dengan desinfektan yang sudah dibuat, diharapkan kegiata ini dapat mereka terapkan dalam kehidupan sehari-hari sebagai bentuk pencegahan dan penularan Covid-19.

\section{Metode Pelaksanaan}

Kegiatan pengabdian kepada masyarakat berupa penyuluhan dan penyemprotan desinfektan ini terbagi menjadi empat tahapan. Tahap pertama adalah tim pengabdian kepada masyarakat melakukan survei ke desa Panca Jaya untuk mengetahui kondisi terkini desa Panca Jaya, melakukan koordinasi dengan kepala desa dan pihak terkait mengenai kegiatan-kegiatan dalam upaya pencegahan dan penularan Covid-19. Selanjutnya tahap kedua, 
tim pengabdian kepada masyarakat menyiapkan alat dan bahan yang akan digunakan dalam pelaksanaan kegiatan penyuluhan, seperti air, cairan pemutih, sarung tangan karet, gelas ukur, corong, botol semprot, alat pemyemprot desinfektan dan pamflet cara pembuatan desinfektan yang akan dibagikan ke warga. Kemudian tahap ketiga, tim pengabdian kepada masyarakat melakukan penyuluhan dan pemyemprotan desinfektan yang diawali dengan penyampaian materi mengenai alat, bahan dan cara pembuatan desinfektan, membagikan pamflate dan desinfektan kepada warga serta melakukan penyemprotan desinfektan di lingkungan desa Panca Jaya.

\section{Hasil dan Pembahasan}

Kegiatan penyuluhan pembuatan dan penyemprotan desinfektan ini dilaksanakan pada hari Senin, 8 November 2021 pukul 08.00 wita di aula desa Panca Jaya. Kegiatan yang didampingi kepala desa dan ketua RT yang di desa Panca Jaya ini berjalan baik dan lancar dengan tetap melaksanakan protokol kesehatan dengan menjaga jarak dan menggunakan masker.

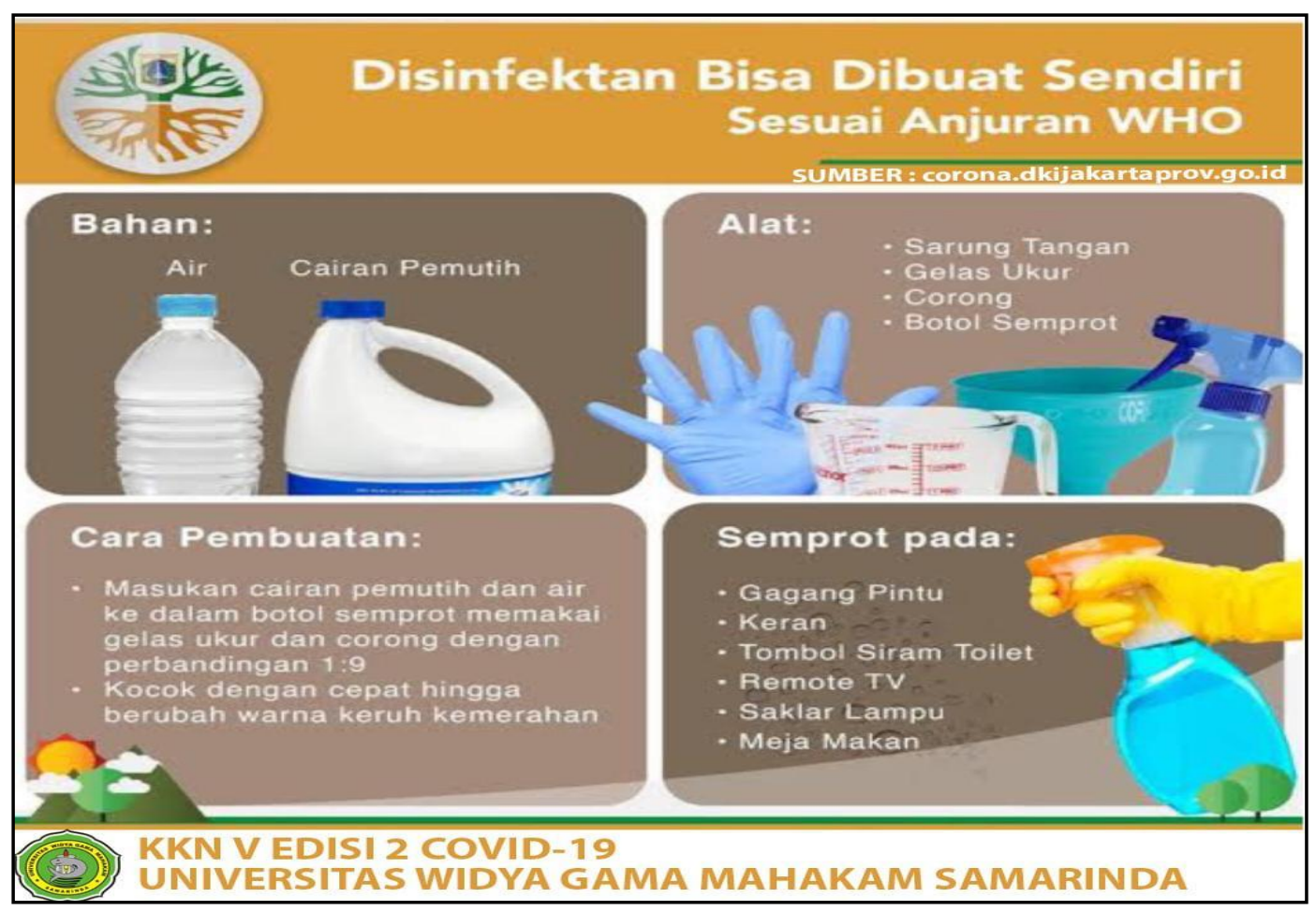

Gambar 1. Pamflate bahan, alat dan cara pembuatan desinfektan

Kegiatan pengabdian kepada masyarakat ini dilakukan dengan beberapa kegiatan. Kegiatan pertama penyuluhan dengan memberikan informasi mengenai bahan, alat serta cara pembuatan desinfektan dengan menampilkan informasi melalui LCD dan pemberian pamflet kepada peserta kegiatan. Kemudian kegiatan dilanjutkan dengan demonstrasi cara pembuatan desinfektan. Desinfektan yang sudah jadi dimasukkan ke dalam botol semprot ukuran $100 \mathrm{ml}$ untuk dibagikan ke peserta kegiatan. 


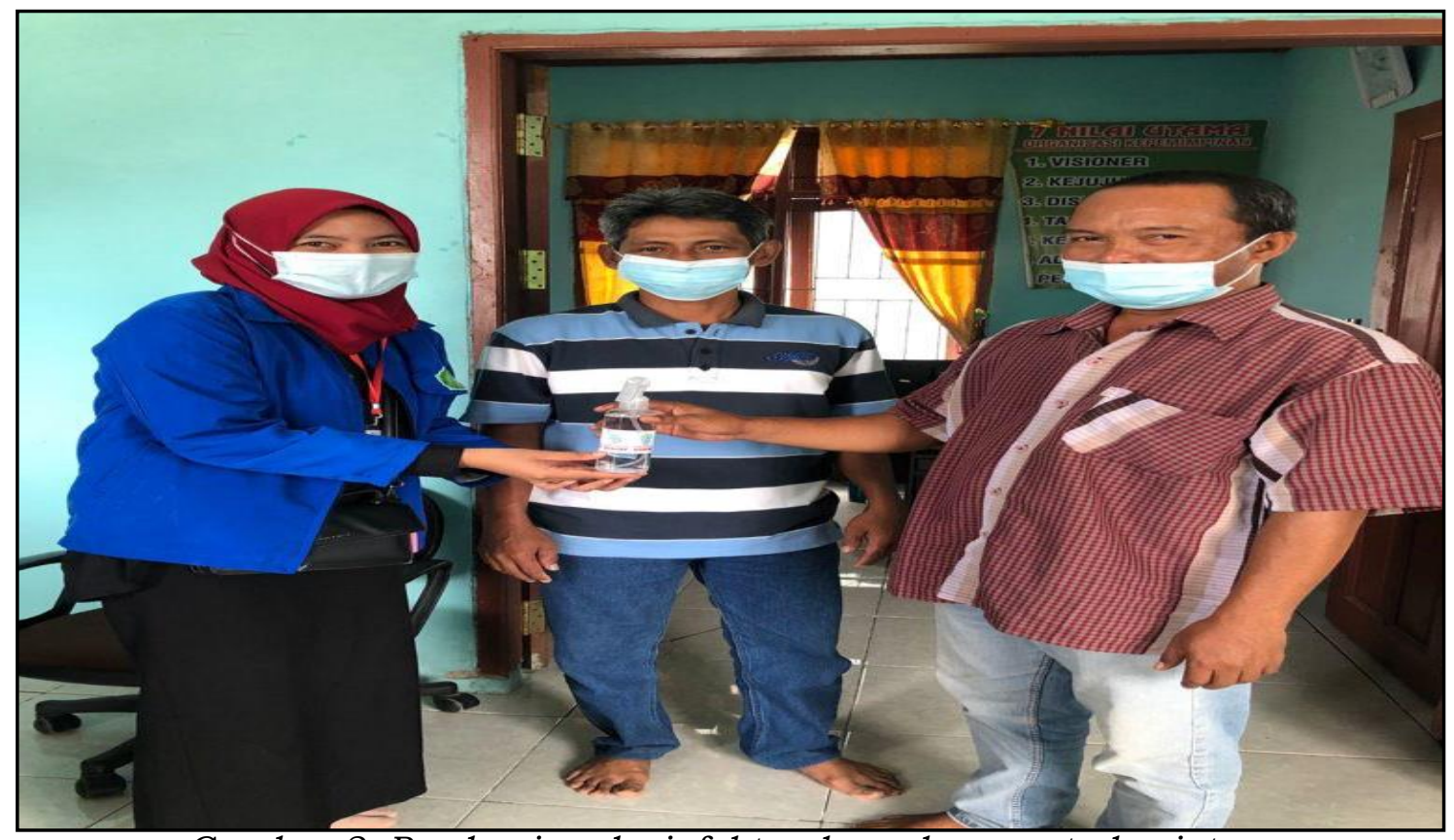

Gambar 2. Pembagian desinfektan kepada peserta kegiatan

Desinfektan yang ada juga dimasukkan ke alat penyemprot kegiatan pengabdian kepada masyarakat dilanjutkan dengan pemyemprotan ke lingkungan desa Panca Jaya.

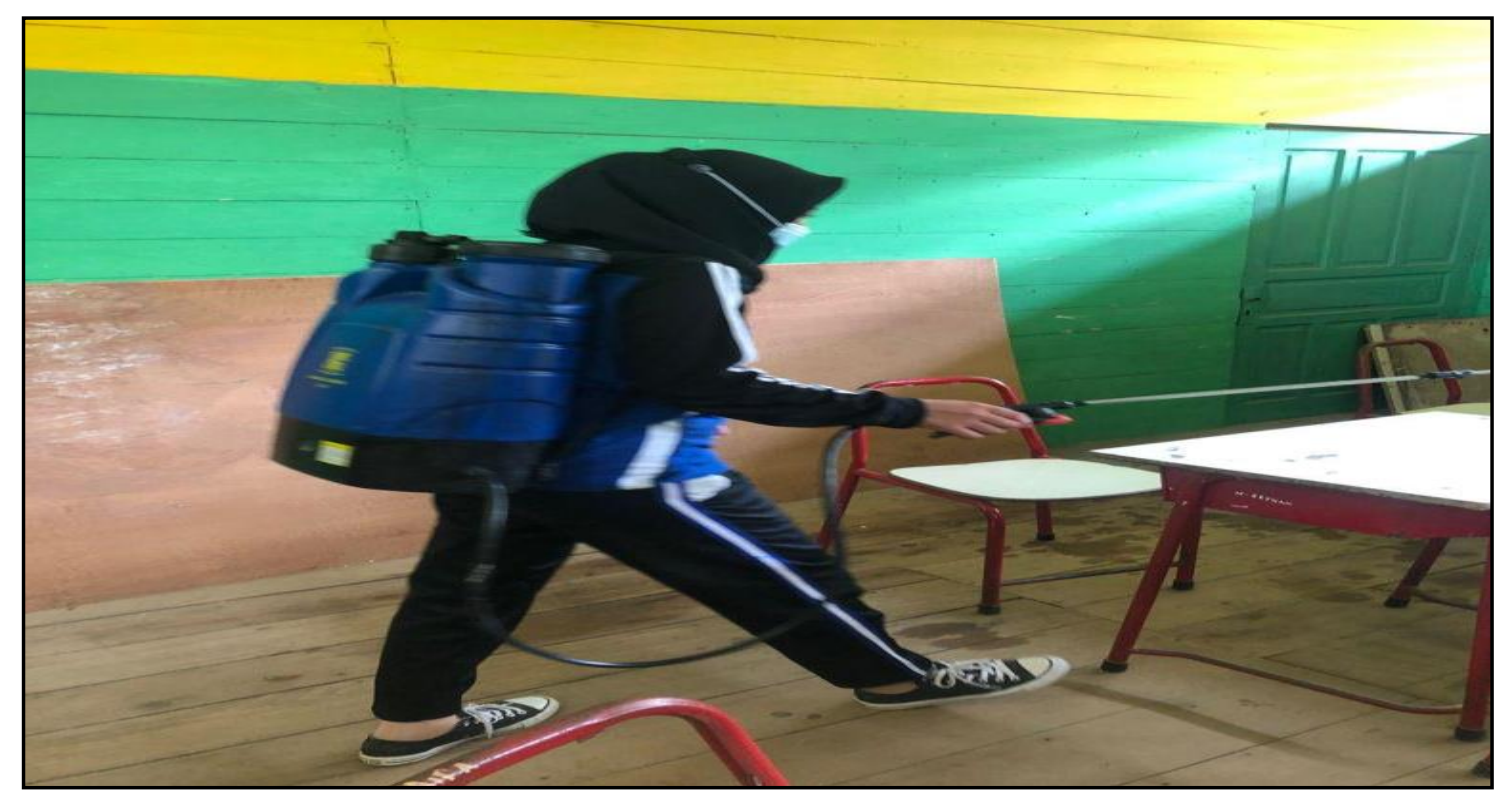

Gambar 3. Penyemprotan desinfektan di lingkungan desa Panca Jaya

Kegiatan penyemprotan desinfektan dilakukan bersama kepala desa dan warga pada tempat-tempat pelayanan publik yaitu kantor kepala desa Panca Jaya, SDI Terpadu Al-Ihsan Muara Kaman, SDN 026 Muara Kaman, SDN 028 Muara Kaman dan masjid sekitar desa Panca Jaya. 


\section{Simpulan dan Tindak Lanjut}

Kegiatan Pengabdian kepada masyarakat berupa Sosialisasi Dan Pelati Hasil pelaksanaan kegiatan pengabdian kepada masyarakat dapat diambil kesimpulan bahwa masyarakat desa Panca Jaya memberi respon positif terhadap kegiatan yang tim pengabdian kepada masyarakat lakukan dan berharap dari kegiatan ini warga dapat membuat desinfektan sendiri serta dapat melakukan pemyemprotan di kawasan rumah warga masing-masing.

\section{Daftar Pustaka}

BUDIAWAN, N. C. (2012). PENURUNAN ANGKA KUMAN DINDING RUANG PERAWATAN DI BALAI PENGOBATAN PENYAKIT PARU-PARU (BP4) KOTAGEDE SETELAH DI DESINFEKSI MENGGUNAKAN DESINFEKTAN "V." Poltekkes Kemenkes Yogyakarta.

Fredy, F., Rahayu, D. P., Lieung, K. W., Purwanty, R., \& Prihandoko, L. A. (2021). Edukasi Protokol Kesehatan dalam Masa Pandemi Covid-19 pada Anak Sekolah Dasar di Pesisir Pantai Payum Merauke. Prima Abdika: Jurnal Pengabdian Masyarakat, 1(2), 73-80. https://doi.org/10.37478/abdika.v1i2.1078

Larasati, A. L., \& Haribowo, C. (2020). Penggunaan Desinfektan dan Antiseptik Pada Pencegahan Penularan Covid-19 di Masyarakat. Majalah Farmasetika, 5(3), 137-145.

Marzuarman, M., Hadi, A., \& Lianda, J. (2020). Bilik Disinfektan Berbasis Ozon (Tanpa Cairan Kimia) Sebagai Upaya Pencegahan Penularan Covid19 Di Lingkungan Upt Puskesmas Desa Pematang Duku Bengkalis. TANJAK, 1(1).

Tribun Jatim. (2020). Cara Membuat Disinfektan Pembunuh Virus Corona dari Wipol, Bayclin, \& 17 Produk Lain, Simak Rumusnya. Retrieved from https://jatim.tribunnews.com/2020/03/29/caramembuat\%02disinfektan-pembunuh-virus-corona-dari-wipol-bayclin-17produk-lain-simak-rumusnya

World Health Organization. (2020). WHO Coronavirus Disease (COVID-19). Retrieved from https:/ / covid19.who.int/?gclid=EAIaIQobChMI4taCysi76QIVDyQrCh0jIgd KEAAYASAAEgJUR_D_BwE

Asharo,R.K., Arifiyanto, A., Khaleyla, F., \& Rahmadi, T. R.(2021).Wawasan Perilaku Hidup Bersih dan Sehat (PHBS) di Masa Kenormalan Baru dalam Upaya Mencegah Penyebaran Covid-19 di Lingkungan Sekolah.Mitra Mahajana: Jurnal Pengabdian Masyarakat,2(2), 184-192. https://doi.org/10.37478/mahajana.v2i2.977

Sijabat, A., \& Sijabat, O. P. (2021). PELATIHAN PEMBUATAN SABUN CAIR UNTUK PENCEGAHAN PENULARAN COVID-19 DI KELURAHAN TIGA BALATA.Mitra Mahajana: Jurnal Pengabdian Masyarakat,2(1). https://doi.org/10.37478/mahajana.v2i1.807 